Article

\title{
Consumer-Oriented Policy towards Diffusion of Electric Vehicles: City-Level Evidence from China
}

\author{
Guoqiang Zhang ${ }^{1}$, Yanmei $\mathrm{Xu}^{1}$ and Juan Zhang ${ }^{2, *}$ \\ 1 School of Economics, UCAS, 80 Zhongguancun East Road of Haidian District, Beijing 100190, China; \\ zhangguoqiang13b@mails.ucas.ac.cn (G.Z.); xuyanmei@ucas.ac.cn (Y.X.) \\ 2 China EV100, 17F Tower A, TusPark Haidian District, Beijing 100084, China \\ * Correspondence: anaskacia@163.com; Tel.: +86-10-6279-0067
}

Academic Editor: Yongrok Choi

Received: 27 September 2016; Accepted: 15 December 2016; Published: 20 December 2016

\begin{abstract}
Public policy is crucial for the diffusion of green innovation, and debates exist about the effects of different policies. This paper explores appropriate types of policy instruments by explaining the quick rise in sales of electric vehicles (EVs) in China. Based on a three-year longitudinal dataset across 88 cities, the study shows that consumer-oriented policies are able to significantly promote EV diffusion. Consumer-oriented policies target consumers to facilitate their usage of cars and lower the lifecycle cost, and typical examples include electricity charging and traffic management. This paper contributes to the literature of clean technology policy in two ways. Firstly, it reveals and empirically tests the importance of consumer-oriented policy instruments for the deployment of green innovation. Secondly, it is one of very few scholarly works offering a detailed review of city-level policies in China's EV industry, which will be useful for scholars who are also interested in similar topics.
\end{abstract}

Keywords: electric vehicle; China; policy instrument; innovation diffusion; pilot city

\section{Introduction}

It is an essential trend in the world today to drive the transition towards sustainability of the economic society through green innovation covering renewable energy, electric vehicles (EVs), wastewater treatment, gas turbines, etc. Due to problems of green innovation, such as high costs of investment, long payback periods, high uncertainty in technology and the market, insufficient infrastructure, and negative impacts on incumbents [1], governments must design effective public policies to promote the diffusion of green innovations. What policy instruments will work most effectively has been a key concern for the academic world and for policy-makers.

This paper targets the types of policy instruments that can effectively promote green technology diffusion with the case of China's EV deployment action. Since China launched a demonstration and deployment program on a large scale in 2009, the government has provided purchase subsidies to stimulate demand. The efforts are not quite effective, however, especially in terms of private passenger cars, with a number of only 5400 in early 2013 [2]. Nevertheless, since the beginning of 2014, there came a sudden explosion in the purchase of passenger cars, with a sales volume up to 189,000 in 2015, ranking number one globally, and accounting for over $30 \%$ of the global total [3,4]. The share of EVs in the entire passenger vehicle market of China rose from $0.03 \%$ in 2013 to $0.90 \%$ in 2015 [5]. Public policy is widely believed to the most important factor that has created and shaped China's EV market [6-9], so a remarkable result may well be attained through proper policies. What policy instruments has the government adopted in order to stimulate the sale of EVs? Which instruments are effective? This paper is going to address these questions.

Generally, market-incentive policies are able to prompt consumers to adopt new technologies by means of economic incentives [10,11]. Various market-incentive policies, including feed-in tariffs, 
tax credits, subsidies, and carbon trades, are applied in many countries to propel wind power, solar photovoltaic, electric vehicles, and other green technologies. The progress in many countries, however, is still slow [12-14]. Therefore, just roughly making use of market-incentive policy instruments will not necessarily promote diffusion; rather, the government should apply more delicate policy instruments. The academia of policy research also attempts to conceive which policies are indeed effective, and many scholars of climate change call for attention on the behavioral economics of potential consumers for policy design [15-17].

Paying heed to the problem, the Chinese government has issued new types of policy instruments, such as traffic management and charging facility expansion, to encourage EV adoption since 2013. A recent investigation summarized the practice with an illuminating dichotomy of policy instruments, i.e., producer-oriented against consumer-oriented policies [6]. Producer-oriented policies target producers directly through lowering cost, improving performance, providing price subsidies and so on, e.g., R\&D support and purchase subsidies. Consumer-oriented policies target consumers to facilitate their usage of cars and to lower the lifecycle cost, e.g., policies on traffic management and electricity charging infrastructure and so on. China's dominant EV policy has transitioned from the producer-oriented type to the consumer-oriented type, which corresponds to the rapid rise of EV sales. In this way, the study implies that consumer-oriented policies are more delicate and effective than conventional market-incentive ones for the diffusion of green technologies, but the study does not provide any empirical work to test the implication.

We use city-level policies and data to fill the gap, because China has selected tens of pilot cities to demonstrate and deploy EVs. There are not only policies from the central government in these cities, but also diversified supporting policies from each city that have significant impacts on EV diffusion. Currently, most academic analyses of China's EV deployment policies either focus on the central government or even the cross-country level [18], obtain data through questionnaire surveys of individual consumers [19], or merely describe some representative pilot cities [20]; however, quantitative analysis covering the whole sample of pilot cities is not in place. This paper will carry out a more detailed study using data of all 88 pilot cities across the country from 2013 to 2015.

Our findings demonstrate that producer-oriented policies cannot necessarily promote EV diffusion, but that consumer-oriented policies, e.g., no restriction on the car plate number, price rebates of electricity charging, and public campaigns, work quite positively and effectively. This inquiry, thus, makes two contributions. Firstly, it presents a comprehensive review of policy instruments in all pilot cities of China, which is a good reference for future researchers. To our knowledge, very few scholarly works have done so. Secondly, it empirically supports existing research about the effects of consumer-oriented policies by analyzing the impacts of different instruments [6], which demonstrates the importance of this type of policy for green technology diffusion.

In the second section the new typology of policy instruments and relevant theories will be introduced and research hypotheses will be proposed. The third section covers the data and research methods. The fourth section reviews China's EV policies in pilot cities, and then quantitatively analyzes the function of different policy instruments. The final section gives policy implications and concluding remarks.

\section{Theoretical Background}

\subsection{Consumer-Oriented and Producer-Oriented Policies}

$\mathrm{Xu}$ and Su suggested a new typology of innovation policy instruments that consist of two types, the producer-oriented and the consumer-oriented [6]. If a policy instrument targets producers directly through lowering costs, improving performance, providing price subsidies, and so on, it is producer-oriented because these measures merely enhance the attractiveness of the product itself, and thereby benefit the producer. Product R\&D subsidies, purchase rebates, and government procurement are all typical producer-oriented policies. Among them, we explain the reason to 
categorize purchase rebates as this type with a few more sentences. In the absence of taxes, purchase subsidies to consumers are equivalent to subsidies for producers. It is just a price discount. In China after 2013, for example, if the on-tag price of a car is 150,000 and the subsidy is 50,000 , then a consumer just pays 100,000 to the car dealer and the government will reimburse 50,000 to the firm. Whether the government reimburses the producer or the consumer ex post makes no essential difference. Who pays the 50,000 first is just a question of policy implementation. If a policy instrument targets consumers directly, e.g., how to use a product conveniently and at a low cost, and how to reduce material and psychological barriers, it belongs to the type of consumer-oriented policy. Policies regarding electricity charging infrastructure, for example, belong to the latter type because infrastructure facilitates the usage of EVs for consumers.

The dichotomy between consumer-oriented and producer-oriented policies exhibits the importance of the costs of consumers during the entire lifecycle of the product and their psychological factors. The lifecycle cost includes not only purchase expenses, but also those of usage and maintenance. Consumers' purchase decisions can also be affected by their psychological feelings, social influence, personal perception, values, and knowledge [16,21]. Producer-oriented policy instruments either have limited impact upon the psychological factors of consumers, or do not reduce time and pecuniary costs of the product during its usage and maintenance, so only producer-oriented policies cannot promote deployment successfully. Empirical evidence of fuel-efficient car sales demonstrates that some consumer-oriented policy instruments, e.g., high-occupancy vehicle (HOV) lanes, income tax credits, and good peer perception, usually exert significant positive effects upon the deployment, and that it is not enough to merely apply purchase subsidies [22-25].

\subsection{Hypotheses about China's Policy Instruments}

There are several categories of consumer-oriented policy instruments. Firstly, policies of electricity charging infrastructure aim to facilitate the charging process of an EV, which is the primary concern of consumers during the car's lifecycle. Policies will be able to promote diffusion if they enable consumers to install and find available charging spots easily and to reduce charging expenses. Hence, we have the hypotheses below.

Hypothesis 1.1: The policy instrument that China's cities have adopted to help consumers find available charging spots promotes EV diffusion.

Hypothesis 1.2: The policy instrument that China's cities have adopted to help consumers install charging spots promotes EV diffusion.

Hypothesis 1.3: The policy instrument that China's cities have adopted to reduce the direct expense of electricity charging promotes EV diffusion.

The second category is concerned with traffic management. Traffic management policies in many cities of China and other countries restrict the expansion of vehicles via a variety of measures, e.g., regulation on granting car plates, high tax rates, and HOV lanes. Some cities such as Beijing and Shanghai attempt to control the total quantity of car plates. Beijing sets a lottery system and Shanghai adopts a bidding system. Only lucky people or those who can afford expensive bidding prices are able to obtain a plate. These policies may, instead, favor fuel-efficient and green vehicles for the sake of sustainable transportation. Typical traffic management policies in China include free and easy accessibility to car plates, special lanes for EVs, unrestricted daily commuting, and free tolls on certain bridges and roads. Restricted daily commuting is a commonly used traffic management policy tool in China. Beijing restricts daily commuting of cars according to the car's last digit on the car plate in order to control the total quantity of vehicles on the road. Cars with 1 and 6 as the last digits of the plate cannot travel on the road on Monday, and those with 2 and 7 cannot travel on Tuesday, and so on. Moreover, the government can also manipulate parking fees. If a policy reduces parking fees for EVs, which is a variant of traffic management, the attractiveness of EVs will greatly increase, especially for people suffering high parking costs in large cities. Thus, we have the next group of hypotheses: 
Hypothesis 2.1: The policy instrument that China's cities have adopted to allow EV owners to easily obtain vehicles plates promotes EV diffusion.

Hypothesis 2.2: The policy instrument that China's cities have adopted to allow EVs to travel on special lanes promotes EV diffusion.

Hypothesis 2.3: The policy instrument that China's cities have adopted to impose no restriction on daily commuting for EVs promotes EV diffusion.

Hypothesis 2.4: The policy instrument that China's cities have adopted to waive tolls on bridges and roads for EVs promotes $\mathrm{EV}$ diffusion.

Hypothesis 2.5: The policy instrument that China's cities have adopted to reduce the parking rates promotes EV diffusion.

The third category is concerned with public campaigns of EVs that address psychological factors and knowledge about EVs to potential consumers. One impediment of the purchase of EVs by private consumers is a lack of knowledge about EVs. If the government, together with EV manufacturers, spread knowledge to residents and invite them to try EVs by means of trial driving or free short-term rentals, potential consumers will probably be determined to buy one. The government may also promote EVs by showing that EVs are environmentally friendly and that the owners of EVs contribute to the environment. Such campaigns will reduce peer pressure and encourage potential consumers to adopt EVs, as is already documented by empirical studies in the United States [22,24]. As a result, we have the last hypothesis:

Hypothesis 3: The public campaign policy that China's cities have adopted promotes EV diffusion.

The next sections will use the cases of Chinese cities to test the hypotheses above, so that we are able to identify truly useful policy instruments for the cities.

\section{Method and Data}

\subsection{Variables and Measures}

We use the longitudinal data of China's 88 pilot cities between 2013 and 2015 to test the hypotheses above. The years between 2009 and 2013 were the first phase of demonstration and deployment, and there were only 25 pilot cities; it was in only five cities where the central government subsidized the private purchase of EVs. When the second phase started in September 2013, the pilot group was enlarged to incorporate 88 cities. This study, therefore, starts from 2013, and the entire dataset is, therefore, composed of 264 city-year dyads.

Table 1 summarizes the variables in the model. Section 3.3 will explain the dependent variable. Here we explain four control variables. Disposable income per capita controls the financial condition of a city's residents, because rich consumers are more likely to buy EVs which are usually more expensive than internal combustion engine cars. If a city also belongs to the pilot group during 2009-2013, its accumulated experience and installed charging infrastructure may well expedite deployment after 2013. We should, thus, control this confounder by setting First ${ }_{i}$ as a control. The variable Cold ${ }_{i}$ controls the climate of a city. If the city is too cold in winter, the temperature will impair the function of batteries severely. Consequently, it is much more difficult to deploy EVs in cold areas. Cities where the average temperature in the coldest month is below $-10{ }^{\circ} \mathrm{C}$ are classified as very cold cities. We obtain the threshold according to a Chinese national standard of architecture heating, GB50176-93. Six cities fall within this group. The last control variable $L o c S u b_{i t}$ represents the local subsidy in order to rule out the important confounder of purchase subsidy, a producer-oriented policy instrument in China. While the subsidy of the central government is the same for all cities, many cities set their local subsidies at a certain fixed ratio of the central subsidy, ranging from 0.5 to 1 . As a result, the ratio reasonably measures the amount of local subsidies. 
Table 1. Variables and measures.

\begin{tabular}{|c|c|c|c|}
\hline Type & Variable & Meaning & Measures \\
\hline \multirow{6}{*}{ Explanatory } & Find $_{i t}$ & $\begin{array}{l}\text { Whether city } i \text { has a policy to help consumers find charging } \\
\text { facilities easily in year } t\end{array}$ & 1 if yes, 0 if not \\
\hline & Install $_{i t}$ & $\begin{array}{l}\text { Whether city } i \text { has a policy to help consumers install charging } \\
\text { facilities easily in year } t\end{array}$ & 1 if yes, 0 if not \\
\hline & chargeRate $_{i t}$ & $\begin{array}{l}\text { Whether city } i \text { has a policy to reduce expense of electricity charging } \\
\text { in year } t\end{array}$ & 1 if yes, 0 if not \\
\hline & Park $_{i t}$ & Whether city $i$ has a policy to reduce parking rates of EVs in year $t$ & 1 if yes, 0 if not \\
\hline & Toll $_{i t}$ & $\begin{array}{l}\text { Whether city } i \text { waives tolls on certain roads and bridges for EV } \\
\text { owners in year } t\end{array}$ & 1 if yes, 0 if not \\
\hline & Campaign $_{i t}$ & $\begin{array}{l}\text { Whether city } i \text { makes public campaigns and advocates trial driving } \\
\text { for EVs in year } t\end{array}$ & 1 if yes, 0 if not \\
\hline \multirow{3}{*}{ Control } & Income $_{i t}$ & Disposable income per capita in city $i$ and year $t$ & Disposable income per capita \\
\hline & First $_{i}$ & Whether city $i$ is a pilot city during 2009-2013 & 1 if yes, 0 if not \\
\hline & Cold $_{i}$ & $\begin{array}{l}\text { Whether city } i \text { is a very cold city in winter whose average } \\
\text { temperature in the coldest month is less than }-10^{\circ} \mathrm{C}\end{array}$ & 1 if yes, 0 if not \\
\hline
\end{tabular}

\subsection{Data}

The data of this paper consists of three parts. The first part is policy data. We collected the policy documents about EVs of the central government from the Government Document Information System (GDIS) at Tsinghua University and collected 330 government-issued documents since the early 1990s. The search keywords included electric vehicle, new energy vehicle, power battery, and clean vehicle. Policy documents of all local governments were obtained from the series of the Yearbook of China's Fuel Economy and New Energy Vehicles that span the period from 2009 to 2015. Then we checked the retrieved policy documents with the database of the China EV100 organization, the most important think-tank specializing in the EV industry in China, to add missing policies. These policy documents, particularly those of local governments, enable us to know which policy instruments the governments adopted to promote the deployment of EVs. We code all of the policy texts of every pilot city from 2013 to 2015 to identify the exact instruments. Noting the fact that announced policy instruments might not be actually implemented, we processed the acquired policies further and kept only two groups of instruments. One group has detailed implementation guidelines in the form of an ensuing separate document (e.g., Guanli Banfa, Shishi Xize in Chinese) or just paragraphs clearly prescribing how to execute the policy. The other group has quantitative specifications that determine the application scope of the policy and is thus easy to execute; for example, the amount of local subsidies and procured government-use cars. If a particular policy instrument belongs to the two groups, we may reasonably regard it as being implemented because firms and consumers are then able to follow the policy immediately. We also cooperate with China EV100 to check the reality in a few pilot cities if we are not sure whether a policy instrument is executed.

We collect all of the economic data of pilot cities from the Statistics Yearbooks of China's Cities and the statistical bulletins of these cities. The data of EV passenger car sales are derived from the Ministry of Public Security of the central government. 


\subsection{Method}

Though the data structure is a balanced panel, the time interval only spans three years and is too short. We treat it as cross-sectional data and use pooled regression to estimate the result. A basic premise of such an operation is that no unobserved heterogeneity is related to the outcome variable among each unit [26]. We may reasonably hold this assumption for two reasons. Firstly, the explanatory and control variables in Table 1 are able to account for most heterogeneity of cities regarding EV car sales, since these local policies are the most frequently applied ones and the economic variables are also key conditions influencing car sales. Secondly, there are too many cities, but the time span is too short, so the degree of freedom of estimation would be very low if 88 fixed effect variables are included. As a result, it is practical to adopt a method to estimate pooled cross-sectional data, and we add a time fixed-effect in the model to reflect heterogeneity in time.

The actual deployment quantity of pilot cities in each year is extremely right-skewed. Many cities have few EV cars in one year while some cities, at the other extreme, deploy more than 1000 cars. Since pilot cities are quite diversified, and even performance of the same city might vary across years due to newly-issued policies, such sharp contrast implies substantially different categories of city-year dyads in terms of deployment achievement, ranging from poor, modest, to good performance. It, therefore, makes sense to treat the deployment result as an ordered multi-class variable rather than an undifferentiated continuous variable. As a result, we set an ordered multi-class dependent variable and use ordered logistic regression instead of ordinary estimation techniques, such as negative binomial and ordinary least square (OLS).

We divide the 264 city-year dyads into five groups whose sales volumes differ by the order of magnitude. Group 1 only deploys nothing or only one car, and performs extremely poorly. This group contains 94 cases. Group 2 deploys two to 10 cars, corresponding to a poor outcome. This group contains 32 cases. Group 3 deploys 11-100 cars and is a modest outcome. It contains 50 cases. Group 4, containing 56 cases, deploys 101-1000 cars, corresponding to a relatively good outcome. The last group containing 32 cases deploys more than 1000 cars and thus performs very well. The five groups form an ordered array, and the dependent variable contains five ordered values accordingly. In addition to ordered logistic regression, we estimate the model with a cluster-robust standard error.

\section{Results}

\subsection{Deployment Policies in China's Pilot Cities}

Chinese EV deployment policies are composed of two levels, at both the central government and pilot cities. The central government's policies mainly include vehicle purchase subsidies, market planning, charging infrastructure planning, and awards to infrastructure in pilot cities. The central government requires all pilot cities to have their own supporting policies, so that both levels combined make efforts to accelerate EV deployment. Table 2 displays certain typical deployment policy instruments in pilot cities which are classified into either the producer-oriented or consumer-oriented type.

Each pilot city varies from the others in issuing supporting policies. By the end of 2015, only 52 of the 88 pilot cities had issued, in total, 20 supporting deployment policies, and the year that a city adopted a specific policy is displayed in Table 3. Among the 52 cities, only four have more than 10 instruments, whereas nearly $70 \%$ of them have less than five instruments. In terms of geographic distribution, most cities with at least seven policy instruments are located in the Yangtze River Delta and Pearl River Delta. Table 3 also exhibits the ratio of national to local subsidies, which shows the generosity of the local government. 
Table 2. Typology of typical deployment policy instruments in pilot cities.

\begin{tabular}{|c|c|c|c|}
\hline Policy Instrument & Producer-Oriented & Consumer-Oriented & Reason \\
\hline $\begin{array}{l}\text { Government } \\
\text { procurement }\end{array}$ & $\star$ & & $\begin{array}{l}\text { Provide a market for } \\
\text { the product }\end{array}$ \\
\hline Extra taxi quota & $\star$ & & $\begin{array}{l}\text { Pull the EV taxi market } \\
\text { for producers }\end{array}$ \\
\hline $\begin{array}{l}\text { Vehicle replacement } \\
\text { subsidy of taxi }\end{array}$ & $\star$ & & $\begin{array}{l}\text { Pull the EV taxi market } \\
\text { for producers }\end{array}$ \\
\hline $\begin{array}{l}\text { Unrestricted car } \\
\text { plate granting }\end{array}$ & & $\star$ & $\begin{array}{l}\text { Easy for EV owners to } \\
\text { get car plates }\end{array}$ \\
\hline Lowering parking rates & & $\star$ & $\begin{array}{c}\text { Lowering the usage cost } \\
\text { of consumers }\end{array}$ \\
\hline $\begin{array}{l}\text { Battery recycling } \\
\text { subsidies }\end{array}$ & & $\star$ & $\begin{array}{l}\text { Remove the trouble of } \\
\text { consumers to deal with } \\
\text { depleted batteries }\end{array}$ \\
\hline Operation subsidy & & $\star$ & $\begin{array}{l}\text { Subsidy for product } \\
\text { operation and usage }\end{array}$ \\
\hline $\begin{array}{l}\text { Low electricity } \\
\text { charging expense }\end{array}$ & & $\star$ & $\begin{array}{c}\text { Lowering the usage cost } \\
\text { of consumers }\end{array}$ \\
\hline $\begin{array}{l}\text { Official service center for } \\
\text { charging facility } \\
\text { installation }\end{array}$ & & $\star$ & $\begin{array}{l}\text { Convenient for } \\
\text { consumers to install } \\
\text { charging facilities }\end{array}$ \\
\hline $\begin{array}{l}\text { Official mobile } \\
\text { applications for finding } \\
\text { charging facilities }\end{array}$ & & $\star$ & $\begin{array}{c}\text { Convenient for } \\
\text { consumers to find nearby } \\
\text { charging facilities }\end{array}$ \\
\hline $\begin{array}{l}\text { Subsidy to firms building } \\
\text { charging stations }\end{array}$ & & $\star$ & $\begin{array}{l}\text { Reducing the cost for } \\
\text { operating firms to build } \\
\text { charging stations }\end{array}$ \\
\hline $\begin{array}{l}\text { Public campaign and } \\
\text { trial driving }\end{array}$ & & $\star$ & $\begin{array}{c}\text { Propagation to address } \\
\text { the behavioral } \\
\text { impediments of } \\
\text { consumers }\end{array}$ \\
\hline Purchase subsidy & $\star$ & & $\begin{array}{l}\text { Actually lower the } \\
\text { product price }\end{array}$ \\
\hline Special lane & & $\star$ & $\begin{array}{l}\text { Convenient for EV } \\
\text { consumers }\end{array}$ \\
\hline Toll-free policy & & $\star$ & $\begin{array}{l}\text { Lowering the usage cost } \\
\text { of consumers }\end{array}$ \\
\hline Unrestricted commuting & & $\star$ & $\begin{array}{l}\text { Convenient for EV } \\
\text { consumers }\end{array}$ \\
\hline
\end{tabular}

Note: $\star$ indicates that the policy instrument belong to the corresponding type. This table is modified from $\mathrm{Xu}$ and $\mathrm{Su}[6]$. Most tax policies are not included here because many tax policies can only be legally enacted by the central government. 
Table 3. City-level deployment policy instruments.

\begin{tabular}{|c|c|c|c|c|c|c|c|c|c|c|c|}
\hline \multirow[b]{2}{*}{ CITY } & \multirow[b]{2}{*}{ TOTAL } & \multicolumn{5}{|c|}{ Producer-Oriented } & \multicolumn{5}{|c|}{ Consumer-Oriented } \\
\hline & & $\begin{array}{l}\text { Local } \\
\text { Purchase } \\
\text { Subsidy }\end{array}$ & $\begin{array}{c}\text { Ratio of } \\
\text { National to } \\
\text { Local Subsidy }\end{array}$ & $\begin{array}{l}\text { Replacement } \\
\text { Subsidy }\end{array}$ & $\begin{array}{c}\text { Extra taxi } \\
\text { Quota }\end{array}$ & $\begin{array}{l}\text { Mandatory } \\
\text { Government } \\
\text { Procurement }\end{array}$ & $\begin{array}{c}\text { Not } \\
\text { Limiting } \\
\text { Car Plates }\end{array}$ & $\begin{array}{l}\text { Public } \\
\text { Campaign }\end{array}$ & $\begin{array}{c}\text { Low } \\
\text { Electricity } \\
\text { Price }\end{array}$ & $\begin{array}{l}\text { Low Charging } \\
\text { Expense }\end{array}$ & $\begin{array}{c}\text { Low Parking } \\
\text { Rates }\end{array}$ \\
\hline Xi'an & 12 & 2013-2015 & $1: 1$ & 2013-2015 & 2013-2015 & 2014-2015 & 2015 & & 2013-2015 & & 2013-2015 \\
\hline Shenzhen & 11 & 2013-2015 & 1:1 & 2013-2015 & 2013-2015 & 2013-2015 & 2015 & & 2013-2015 & & 2013-2015 \\
\hline Shanghai & 10 & 2013-2015 & $1: 1$ & & & 2013-2015 & 2013-2015 & 2013-2015 & 2013-2015 & & \\
\hline Hefei & 10 & 2014-2015 & $1: 1$ & 2014-2015 & & 2014-2015 & 2015 & & 2014-2015 & 2014-2015 & 2014-2015 \\
\hline Beijing & 5 & 2014-2015 & $1: 1$ & 2015 & & & 2013-2015 & & & 2015 & \\
\hline Nanjing & 7 & 2013-2014 & $1: 1$ & & & 2015 & 2015 & & 2015 & 2014-2015 & \\
\hline Nanchang & 4 & 2014-2015 & 1:1 & & & & 2015 & & & & \\
\hline Wuhu & 8 & 2013-2015 & $1: 0.3$ & 2013-2015 & & 2013-2015 & 2015 & & & & 2013-2015 \\
\hline Wuhan & 7 & 2014-2015 & $1: 1$ & & & 2014-2015 & & & & & \\
\hline Ningbo & 6 & 2014-2015 & $1: 1$ & & & & & & & & \\
\hline Hangzhou & 3 & 2013-2015 & $1: 1$ & & & & 2014-2015 & & & & \\
\hline Guangzhou & 7 & 2013-2015 & 1:1 & & & 2013-2015 & 2013-2015 & & & & \\
\hline Kunming & 4 & 2014-2015 & $1: 0.5$ & & & & & & & & 2014-2015 \\
\hline Xiamen & 7 & 2014-2015 & $1: 1$ & & & 2014-2015 & & & 2014-2015 & & \\
\hline Weifang & 6 & 2014-2015 & $1: 1$ & & & & & & 2014-2015 & 2014-2015 & \\
\hline Yichun & 4 & 2015 & 1:0.6 & & & 2015 & & & & & 2015 \\
\hline Zhengzhou & 1 & & & & & 2013-2015 & & & & & \\
\hline Taiyuan & 7 & 2014-2015 & $1: 1$ & & & 2014-2015 & & & 2014-2015 & 2014-2015 & 2014-2015 \\
\hline Xingtai & 4 & & & & & 2014-2015 & & & 2014-2015 & & \\
\hline Luzhou & 3 & 2014-2015 & 1:1 & & & & & & & & 2014-2015 \\
\hline Linyi & 2 & 2014-2015 & $1: 0.6$ & & & & & & & & \\
\hline Xiangyang & 4 & 2013-2015 & $1: 1$ & & & 2013-2015 & & & & & \\
\hline Chongqing & 3 & 2013-2015 & 1:1 & & & & & & & & \\
\hline Tianjing & 3 & 2013-2015 & $1: 1$ & & & 2013-2015 & 2014-2015 & & & & \\
\hline Shijiazhuang & 7 & 2014-2015 & 1:1 & & & 2014-2015 & 2013-2015 & & & & \\
\hline Nantong & 4 & 2013-2015 & 1:1 & & & & & & 2013-2015 & 2013-2015 & \\
\hline Yancheng & 4 & 2014-2015 & $1: 1$ & & & & & & $2014-2015$ & 2014-2015 & \\
\hline Bijie & 1 & & & & & 2014 & & & & & \\
\hline Huizhou & 7 & 2013-2015 & 1:1 & & & & & & 2015 & 2015 & 2013-2015 \\
\hline Jinhua & 2 & 2013 & $1: 1$ & & & & & & & & \\
\hline Dongguan & 4 & 2013-2015 & $1: 1$ & & & 2015 & & & & & \\
\hline Dalian & 3 & 2013-2015 & $1: 1.25$ & & & 2013-2015 & & & & & \\
\hline Putian & 4 & 2014-2015 & 1:1 & & & 2014-2015 & & & 2014-2015 & & \\
\hline Changzhou & 4 & 2013-2014 & $1: 0.6$ & & & & & & 2013-2014 & 2013-2014 & \\
\hline Zhuzhou & 2 & 2013-2015 & $1: 1$ & & & & & & 2013-2015 & & \\
\hline Xinxiang & 3 & 2014-2015 & $1: 1$ & & & & & & & & \\
\hline Ganzhou & 3 & 2014-2015 & $1: 1$ & & & 2014-2015 & & & & & \\
\hline Qingdao & 2 & 2014-2015 & 1:1 & & & & & & & & \\
\hline
\end{tabular}


Table 3. Cont

\begin{tabular}{|c|c|c|c|c|c|c|c|c|c|c|c|}
\hline \multirow[b]{2}{*}{ CITY } & \multirow[b]{2}{*}{ TOTAL } & \multicolumn{5}{|c|}{ Producer-Oriented } & \multicolumn{5}{|c|}{ Consumer-Oriented } \\
\hline & & $\begin{array}{c}\text { Local } \\
\text { Purchase } \\
\text { Subsidy }\end{array}$ & $\begin{array}{c}\text { Ratio of } \\
\text { National to } \\
\text { Local Subsidy }\end{array}$ & $\begin{array}{l}\text { Replacement } \\
\text { Subsidy }\end{array}$ & $\begin{array}{c}\text { Extra taxi } \\
\text { Quota }\end{array}$ & $\begin{array}{c}\text { Mandatory } \\
\text { Government } \\
\text { Procurement }\end{array}$ & $\begin{array}{c}\text { Not } \\
\text { Limiting } \\
\text { Car Plates }\end{array}$ & $\begin{array}{c}\text { Public } \\
\text { Campaign }\end{array}$ & $\begin{array}{c}\text { Low } \\
\text { Electricity } \\
\text { Price }\end{array}$ & $\begin{array}{l}\text { Low Charging } \\
\text { Expense }\end{array}$ & $\begin{array}{c}\text { Low Parking } \\
\text { Rates }\end{array}$ \\
\hline Zhuhai & 1 & $2014-2015$ & 1:0.5 & & & & & & & & \\
\hline Suzhou & 4 & 2013-2014 & 1:0.6 & & & & & & 2013-2014 & 2013-2014 & \\
\hline Haikou & 2 & 2014-2015 & 1:0.6 & & & & & & & & \\
\hline Pingxiang & 1 & 2014-2015 & 1:0.6 & & & & & & & & \\
\hline Changchun & 6 & 2014-2015 & $1: 1$ & & & & & & & & \\
\hline Yangzhou & 2 & $2013-2015$ & $1: 1$ & & & & & & & & \\
\hline Nanping & 1 & & & & & 2015 & & & & & \\
\hline Jincheng & 2 & & & & & & & & 2015 & & 2015 \\
\hline Longyan & 1 & 2014-2015 & $1: 1$ & & & & & & & & \\
\hline Shaoxing & 3 & 2014-2015 & $1: 1$ & & 2014-2015 & 2014-2015 & & & & & \\
\hline Foshan & 2 & 2014-2015 & $1: 1$ & & & & & & & 2015 & \\
\hline Lanzhou & 1 & 2015 & $1: 1$ & & & & & & & & \\
\hline Guiyang & 1 & & & & & & 2013-2015 & & & & \\
\hline Changsha & 1 & 2014-2015 & $1: 1$ & & & & & & & & \\
\hline \multirow[b]{2}{*}{ CITY } & \multicolumn{11}{|c|}{ Consumer-Oriented } \\
\hline & $\begin{array}{l}\text { Special } \\
\text { Lane }\end{array}$ & $\begin{array}{l}\text { Unrestricted } \\
\text { Commuting }\end{array}$ & Toll-Free & $\begin{array}{c}\text { Low } \\
\text { Vehicle } \\
\text { Examination } \\
\text { Fee }\end{array}$ & $\begin{array}{c}\text { Low } \\
\text { Insurance } \\
\text { Fee }\end{array}$ & $\begin{array}{l}\text { Operation } \\
\text { Subsidy to } \\
\text { EV Taxi }\end{array}$ & $\begin{array}{l}\text { Battery } \\
\text { Recycling } \\
\text { Subsidy }\end{array}$ & $\begin{array}{c}\text { Service Center } \\
\text { for Convenient } \\
\text { Charging } \\
\text { Facility } \\
\text { Installation }\end{array}$ & $\begin{array}{l}\text { Subsidy for } \\
\text { Building } \\
\text { Charging } \\
\text { Stations }\end{array}$ & $\begin{array}{l}\text { Prioritized Land } \\
\text { Allocation for } \\
\text { Charging } \\
\text { Facility } \\
\text { Building }\end{array}$ & $\begin{array}{c}\text { Official } \\
\text { Mobile Apps } \\
\text { for Finding } \\
\text { Charging } \\
\text { Facilities }\end{array}$ \\
\hline Xi'an & 2013-2015 & & & 2013-2015 & 2013-2015 & & & & 2013-2015 & 2013-2015 & \\
\hline Shenzhen & & & & & & & 2013-2015 & 2013-2015 & $2013-2015$ & $2013-2015$ & \\
\hline Shanghai & & & & & & & 2014-2015 & 2013-2015 & 2013-2015 & 2013-2015 & 2015 \\
\hline Hefei & & & & & 2014-2015 & & 2014-2015 & & 2014-2015 & & \\
\hline Beijing & & 2015 & & & & & & & & & \\
\hline Nanjing & & & & & & & & & 2013-2015 & 2015 & \\
\hline Nanchang & & 2015 & & & & & & & 2014-2015 & & \\
\hline Wuhu & & & & & & 2013-2015 & & & 2013-2015 & & 2013-2015 \\
\hline Wuhan & 2014-2015 & 2014-2015 & 2014-2015 & & & & & & 2014-2015 & 2014-2015 & \\
\hline Ningbo & & 2014-2015 & 2014-2015 & 2014-2015 & & & & 2014-2015 & 2014-2015 & & \\
\hline Hangzhou & & & & & & & & & 2013-2015 & & \\
\hline Guangzhou & & & & 2013-2015 & & & 2013-2015 & 2013-2015 & 2013-2015 & & \\
\hline Kunming & & 2014-2015 & & & & & & 2014-2015 & & & \\
\hline Xiamen & 2014-2015 & & & 2014-2015 & & & & & 2014-2015 & 2014-2015 & \\
\hline Weifang & & & & & & & & 2014-2015 & 2014-2015 & 2014-2015 & \\
\hline Yichun & & & & & & & & & 2015 & & \\
\hline Zhengzhou & & & & & & & & & & & \\
\hline
\end{tabular}


Table 3. Cont.

\begin{tabular}{|c|c|c|c|c|c|c|c|c|c|c|c|}
\hline \multirow[b]{2}{*}{ CITY } & \multicolumn{11}{|c|}{ Consumer-Oriented } \\
\hline & $\begin{array}{l}\text { Special } \\
\text { Lane }\end{array}$ & $\begin{array}{l}\text { Unrestricted } \\
\text { Commuting }\end{array}$ & Toll-Free & $\begin{array}{c}\text { Low } \\
\text { Vehicle } \\
\text { Examination } \\
\text { Fee }\end{array}$ & $\begin{array}{c}\text { Low } \\
\text { Insurance } \\
\text { Fee }\end{array}$ & $\begin{array}{c}\text { Operation } \\
\text { Subsidy to } \\
\text { EV Taxi }\end{array}$ & $\begin{array}{l}\text { Battery } \\
\text { Recycling } \\
\text { Subsidy }\end{array}$ & $\begin{array}{c}\text { Service Center } \\
\text { for Convenient } \\
\text { Charging } \\
\text { Facility } \\
\text { Installation }\end{array}$ & $\begin{array}{l}\text { Subsidy for } \\
\text { Building } \\
\text { Charging } \\
\text { Stations }\end{array}$ & $\begin{array}{l}\text { Prioritized Land } \\
\text { Allocation for } \\
\text { Charging } \\
\text { Facility } \\
\text { Building }\end{array}$ & $\begin{array}{c}\text { Official } \\
\text { Mobile Apps } \\
\text { for Finding } \\
\text { Charging } \\
\text { Facilities }\end{array}$ \\
\hline Taiyuan & & & & & & & & & $2014-2015$ & $2014-2015$ & \\
\hline Xingtai & & & 2014-2015 & & & & & & & 2014-2015 & \\
\hline Luzhou & 2014-2015 & & & & & & & & & & \\
\hline Linyi & & & & & & & & & 2014-2015 & & \\
\hline $\begin{array}{l}\text { Chongqing } \\
\text { Tianjing }\end{array}$ & & 2013-2015 & & & & & & & $2013-2015$ & & \\
\hline Shijiazhuang & & 2014-2015 & 2014-2015 & 2014-2015 & & & & & 2014-2015 & & \\
\hline Nantong & & & & & & & & & 2013-2015 & & \\
\hline $\begin{array}{c}\text { Yancheng } \\
\text { Bijie }\end{array}$ & & & & & & & & & 2014-2015 & & \\
\hline $\begin{array}{c}\text { Huizhou } \\
\text { Jinhua }\end{array}$ & & & & 2013-2015 & & & & 2015 & $\begin{array}{c}2015 \\
2014-2015\end{array}$ & & \\
\hline Dongguan & & & & & & & & & 2014-2015 & 2015 & \\
\hline Dalian & & 2013-2015 & & & & & & & & & \\
\hline Putian & & & & & & & & & 2014-2015 & & \\
\hline Xinxiang & & & & & & & & & 2014-2015 & 2014-2015 & \\
\hline Ganzhou & & & & 2014-2015 & & & & & & & \\
\hline $\begin{array}{l}\text { Qingdao } \\
\text { Zhuhai }\end{array}$ & & & & & & & & & 2014-2015 & & \\
\hline Suzhou & & & & & & & & & 2013-2014 & & \\
\hline Haikou & & & & & & & & & 2014-2015 & & \\
\hline Pingxiang & & & & & & & & & & & \\
\hline Changchun & & 2014 & & 2014 & & & & 2014 & 2014 & 2014 & \\
\hline Yangzhou & & & & & & & & & $2013-2015$ & & \\
\hline Nanping & & & & & & & & & & & \\
\hline Jincheng & & & & & & & & & & & \\
\hline Longyan & & & & & & & & & & & \\
\hline Shaoxing & & & & & & & & & & & \\
\hline Foshan & & & & & & & & & & & \\
\hline Lanzhou & & & & & & & & & & & \\
\hline Guiyang & & & & & & & & & & & \\
\hline Changsha & & & & & & & & & & & \\
\hline
\end{tabular}




\subsection{Effects of City-Level Policy Instruments}

Table 4 displays the descriptive statistics of all the variables. Table 5 exhibits the ordered logistic regression results that are run with STATA. Model 1 displays a full model, and the other three test the three groups of explanatory variables, respectively, namely electricity charging, traffic management, and public campaigns. Most control variables, and the two time-fixed effects, are significant in the four models, as we expected. Cities with a high income per capita, for instance, deploy more EVs. A cold climate in pilot cities, for another, impedes the deployment. The experience of cities in the first pilot batch between 2009 and 2012 helps them to outperform their counterparts. However, the effect of local purchase subsidy is unexpected. Though it can generally positively increase EV passenger car sales, the significances in Model 1 and Model 2 are not strong and its effect in Model 3 is even insignificant. Hence, the local purchase subsidy is not as effective as we usually assume.

The first group of hypotheses inspects policies of electricity charging. Hypothesis 1.1 cannot be rejected because the variable Find ${ }_{i t}$ is significant in Model 1 and Model 2. The official mobile applications enabling consumers to capture charging facilities nearby really promote EV sales because it lessens the crucial worry of potential consumers. The variable Install it is insignificant and, thus, Hypothesis 1.2 is rejected. Perhaps potential consumers do not care whether policy may expedite the installation of charging facilities when they make purchase decisions, and they are willing to wait for a longer time. The variable chargeRate $_{i t}$ is moderately significant in the full model and very significant in Model 2. This means that reducing the electricity charging rate may also stimulate EV sales, which supports Hypothesis 1.3.

The second group of hypotheses examines traffic management policies. Hypothesis 2.1 is supported because of the significant variable carPlate $_{i t}$. The result is consistent with the fact that the easy granting of EV car plates is a particularly important impulse of EV sales growth in large cities, such as Beijing and Shanghai. The significant correlation between carPlate $_{i t}$ and the dependent variable in Table 4 also supports the claim to a certain extent. Hypothesis 2.2 is rejected because Lane $_{i t}$ negatively influences EV sales, which cannot be explicated reasonably. Free tolls on highways for EVs can promote EV sales slightly, as is displayed by its significance in Model 3, though it is not significant in Model 1. Hypothesis 2.3 is rejected because Commuting ${ }_{i t}$ is not significant in Model 1 or Model 3. Hypothesis 2.4 cannot be rejected, accordingly. The outcome of Park $_{i t}$ in the two models clearly supports Hypothesis 2.5, and reducing parking rates enhances EV sales.

The results of variable Campaign ${ }_{i t}$ in Model 1 and Model 4 strongly favor Hypothesis 3, and demonstrate the importance of public campaigns and trial driving to persuade potential consumers. Table 6 summarizes the final outcome of all these hypotheses. 
Table 4. Descriptive statistics of variables.

\begin{tabular}{|c|c|c|c|c|c|c|c|c|c|c|c|c|c|c|c|c|}
\hline & Mean & Std. & Group & Income & First & Cold & LocSub & carPlate & Campaign & chargeRate & Lane & Commuting & Toll & Install & Find & Park \\
\hline Group & 2.6589 & 0.090 & 1 & & & & & & & & & & & & & \\
\hline Income & 30199 & 7615 & $0.4742 *$ & 1 & & & & & & & & & & & & \\
\hline First & 0.279 & 0.449 & 0.3085 * & 0.3689 * & 1 & & & & & & & & & & & \\
\hline Cold & 0.0698 & 0.255 & -0.1460 * & -0.0121 & 0.1349 * & 1 & & & & & & & & & & \\
\hline LocSub & 0.335 & 0.466 & 0.4191 * & 0.4180 * & $0.3262 *$ & -0.0433 & 1 & & & & & & & & & \\
\hline carPlate & 0.0969 & 0.296 & $0.3042 *$ & 0.3270 * & 0.2636 * & -0.0897 & 0.2517 * & 1 & & & & & & & & \\
\hline Campaign & 0.0116 & 0.107 & 0.1508 * & 0.2565 * & 0.1743 * & -0.0297 & 0.1552 * & $0.3311 *$ & 1 & & & & & & & \\
\hline chargeRate & 0.0271 & 0.163 & $0.1716^{*}$ & -0.0514 & 0.00250 & -0.0457 & 0.0286 & 0.0259 & -0.0181 & 1 & & & & & & \\
\hline Lane & 0.0349 & 0.184 & $0.1427^{*}$ & 0.0957 & 0.0701 & -0.0521 & 0.2720 * & 0.00910 & -0.0206 & $0.2283 *$ & 1 & & & & & \\
\hline Commuting & 0.0659 & 0.249 & 0.1926 * & 0.121 & 0.2876 * & -0.0114 & 0.3380 * & $0.1243^{*}$ & -0.0288 & 0.1480 * & 0.120 & 1 & & & & \\
\hline Toll & 0.0426 & 0.202 & $0.2093 *$ & 0.1606 * & 0.0826 & -0.0578 & 0.2194 * & $0.1254 *$ & -0.0229 & 0.4371 * & 0.1690 * & 0.4079 * & 1 & & & \\
\hline Install & 0.0659 & 0.249 & 0.2250 * & 0.3649 * & 0.2527 * & -0.0114 & 0.3464 * & 0.2827 * & $0.4084^{*}$ & -0.0444 & -0.0505 & 0.2443 * & 0.3306 * & 1 & & \\
\hline Find & 0.0233 & 0.151 & $0.1967^{*}$ & 0.0828 & -0.0387 & -0.0423 & 0.105 & 0.2103 * & 0.2232 * & $0.4491 *$ & 0.2510 * & -0.0410 & -0.0326 & 0.0627 & 1 & \\
\hline Park & 0.0930 & 0.291 & 0.2697 * & 0.1300 * & 0.0685 & -0.0877 & 0.3119 * & 0.1657 * & 0.2142 * & 0.1929 * & 0.3027 * & 0.0225 & $0.1306^{*}$ & $0.3452 *$ & $0.4818^{*}$ & 1 \\
\hline
\end{tabular}


Table 5. Empirical results.

\begin{tabular}{|c|c|c|c|c|}
\hline & (1) & (2) & (3) & (4) \\
\hline Year 2014 & $\begin{array}{c}2.787^{* * * *} \\
(6.28)\end{array}$ & $\begin{array}{c}2.647^{* * *} \\
(6.34)\end{array}$ & $\begin{array}{c}2.673^{* * * *} \\
(6.31)\end{array}$ & $\begin{array}{c}2.662 * * * \\
(6.20)\end{array}$ \\
\hline Year 2015 & $\begin{array}{c}5.590 * * * \\
(8.99)\end{array}$ & $\begin{array}{c}5.421^{* * *} \\
(9.37)\end{array}$ & $\begin{array}{c}5.304^{* * *} \\
(9.06)\end{array}$ & $\begin{array}{c}5.278^{* * *} \\
(8.98)\end{array}$ \\
\hline Income $_{\text {it }}$ & $\begin{array}{c}0.000124^{* * * *} \\
(4.89)\end{array}$ & $\begin{array}{c}0.000123 \\
(4.99)\end{array}$ & $\begin{array}{c}0.000114^{* * * *} \\
(4.90)\end{array}$ & $\begin{array}{c}0.000112 \text { **** } \\
(4.70)\end{array}$ \\
\hline First $_{i}$ & $\begin{array}{c}1.888^{* * *} \\
(4.77)\end{array}$ & $\begin{array}{c}1.806^{* * *} \\
(4.79)\end{array}$ & $\begin{array}{c}1.781 * * * \\
(4.63)\end{array}$ & $\begin{array}{c}1.629 * * * \\
(4.48)\end{array}$ \\
\hline Cold $_{i}$ & $\begin{array}{c}-2.435^{* * *} \\
(-6.67)\end{array}$ & $\begin{array}{c}-2.582 * * * \\
(-6.57)\end{array}$ & $\begin{array}{c}-2.347^{* * *} \\
(-6.69)\end{array}$ & $\begin{array}{c}-2.506^{* * *} \\
(-7.25)\end{array}$ \\
\hline $\operatorname{LocSub}_{i t}$ & $\begin{array}{c}0.729 * \\
(1.96)\end{array}$ & $\begin{array}{c}0.736 \text { ** } \\
(2.18)\end{array}$ & $\begin{array}{l}0.583 \\
(1.58)\end{array}$ & $\begin{array}{c}0.798 * * \\
(2.50)\end{array}$ \\
\hline carPlate $_{i t}$ & $\begin{array}{c}1.121^{* *} \\
(2.25)\end{array}$ & & $\begin{array}{c}1.310^{* *} \\
(2.38)\end{array}$ & \\
\hline Lane $_{i t}$ & $\begin{array}{c}-1.433^{* * *} \\
(-4.86)\end{array}$ & & $\begin{array}{l}-0.654 \\
(-1.35)\end{array}$ & \\
\hline Commuting $_{i t}$ & $\begin{array}{l}-0.198 \\
(-0.48)\end{array}$ & & $\begin{array}{l}-0.449 \\
(-1.14)\end{array}$ & \\
\hline Toll $_{i t}$ & $\begin{array}{l}1.165 * \\
(1.84)\end{array}$ & & $\begin{array}{c}1.348^{* * *} \\
(3.02)\end{array}$ & \\
\hline Park $_{i t}$ & $\begin{array}{c}1.175^{* * *} \\
(3.25)\end{array}$ & & $\begin{array}{c}1.556^{* * *} \\
(2.66)\end{array}$ & \\
\hline Campaign $_{i t}$ & $\begin{array}{c}2.762 * \\
(1.88)\end{array}$ & & & $\begin{array}{c}2.371^{* * *} \\
(4.19)\end{array}$ \\
\hline Install $_{i t}$ & $\begin{array}{l}-0.802 \\
(-0.98)\end{array}$ & $\begin{array}{l}0.286 \\
(0.47)\end{array}$ & & \\
\hline Find $_{i t}$ & $\begin{array}{c}2.974^{* * *} \\
(5.88)\end{array}$ & $\begin{array}{c}3.048^{* * *} \\
(7.64)\end{array}$ & & \\
\hline chargeRate $_{i t}$ & $\begin{array}{c}1.361^{* *} \\
(2.09)\end{array}$ & $\begin{array}{c}1.992^{* * *} \\
(4.93)\end{array}$ & & \\
\hline cut1_cons & $\begin{array}{c}5.630^{* * *} \\
(6.57)\end{array}$ & $\begin{array}{c}5.488^{* * *} \\
(6.70)\end{array}$ & $\begin{array}{c}5.234^{* * *} \\
(6.62)\end{array}$ & $\begin{array}{c}5.086^{* * *} \\
(6.28)\end{array}$ \\
\hline cut2_cons & $\begin{array}{c}6.934^{* * *} \\
(7.61)\end{array}$ & $\begin{array}{c}6.745^{* * *} \\
(7.77)\end{array}$ & $\begin{array}{c}6.486^{* * *} \\
(7.60)\end{array}$ & $\begin{array}{c}6.296 * * * \\
(7.22)\end{array}$ \\
\hline cut3_cons & $\begin{array}{c}8.944^{* * *} \\
(8.81)\end{array}$ & $\begin{array}{c}8.676^{* * *} \\
(9.11)\end{array}$ & $\begin{array}{c}8.377^{* * *} \\
(8.78)\end{array}$ & $\begin{array}{c}8.099 * * * \\
(8.38)\end{array}$ \\
\hline cut4_cons & $\begin{array}{c}11.77^{* * *} \\
(10.20)\end{array}$ & $\begin{array}{c}11.40^{* * *} \\
(10.44)\end{array}$ & $\begin{array}{c}11.08^{* * *} \\
(10.19)\end{array}$ & $\begin{array}{c}10.64^{* * *} \\
(9.89)\end{array}$ \\
\hline Pseudo $R^{2}$ & 0.3971 & 0.3827 & 0.3761 & 0.3577 \\
\hline$N$ & 264 & 264 & 264 & 264 \\
\hline
\end{tabular}

Table 6. Results of hypotheses testing.

\begin{tabular}{cccccccccc}
\hline Hypothesis & 1.1 & 1.2 & 1.3 & 2.1 & 2.2 & 2.3 & 2.4 & 2.5 & 3 \\
\hline Result & $\sqrt{ }$ & $\times$ & $\sqrt{ }$ & $\sqrt{ }$ & $\times$ & $\times$ & $\sqrt{ }$ & $\sqrt{ }$ & $\sqrt{ }$ \\
\hline \multicolumn{1}{c}{$\sqrt{ }$ represents support, $\times$ represents rejection. }
\end{tabular}




\section{Discussions and Conclusions}

\subsection{Discussions and Policy Implications}

The results in the previous section indicate that policy instruments of the consumer-oriented group are effective to promote EV deployment, apart from purchase subsidies. Consumer-oriented policies play their role in three aspects, namely electricity charging, traffic management, and public campaigns. Policies to help consumers find electricity charging facilities, to reduce charging rates, to cut parking rates, to grant car plates unrestrictedly, and to enable trial driving can all effectively encourage potential consumers to buy EVs. The city-level results not only verify many researchers' theoretical explorations into consumer preferences and consumer-oriented policies at the national level $[6,14]$, but also correspond to micro-level data obtained through questionnaire surveys $[19,27,28]$. The effects of special lanes are not yet obvious, which might be due to the reason that most cities in China have not implemented this policy. This result also agrees with Diamond's study on the mixed effects of HOV policies for hybrid electric vehicle (HEV) diffusion in Virginia [29]. Surprisingly, the local purchase subsidy, a typical producer-oriented policy instrument, is not so effective for deployment. This fact reinforces the importance of consumer-oriented policies from the opposite side.

The diffusion journey of green technologies and products is similar to a marketing process, in a certain sense. The government wants to attract potential adopters in order to better stimulate the diffusion of new technologies, which resembles "selling" technologies to consumers. It acts like an enterprise through marketing campaigns to transform the current market and should, therefore, analyze both the economic decisions and behavioral characteristics of consumers [30]. Policies hitting the sore points of potential consumers are likely to be effective, and those failing to address their true concerns are will have difficulty being successful.

Concrete measures include closely tracking consumer preferences and constantly learning and adjusting policy in practice [31-33]. In addition to material incentives, such as one-off purchase subsidies and tax exemptions, policies should take into account consumers' cost and convenience during the usage of cars, and more consumer-oriented policies should be adopted. For instance, policies to facilitate electricity charging and to reduce charging costs and parking costs should play a long-term role while consumers are using their vehicles, as they are also significant concerns for consumers, and should be emphasized in the future. Moreover, with more and more vehicles in cities, restricting traditional vehicle purchases and favoring purchases of EVs have proved to be effective in Beijing and Shanghai. The practice may be replicated in other pilot cities so that consumers have to buy EVs instead of fuel vehicles. Finally, public campaigns on EVs should be reinforced, creating favorable conditions for trial driving and EV leasing, and enabling more consumers to experience the merits of EVs during trial driving and leasing. Additionally, they can have a sense of pride from protecting the environment via buying EVs and, accordingly, tend to suffer less mental burden.

\subsection{Conclusions and Future Research}

This paper employs a short panel of 88 of China's pilot cities for EV deployment between 2013 and 2015 to investigate what kind of policy instruments have promoted China's amazingly quick increase of EV sales. Consumer-oriented policy instruments that are concerned with electricity charging facilities, traffic management, and public campaigns prove to be effective for deployment. Thus, we contribute to the literature in two ways. For one thing, we have empirically tested the importance of consumer-oriented policy instruments for EV deployment. For another, this paper is one of the earliest works on China's EVs that uses city-level data, which supplements the numerous studies based on either cross-country policy comparison or consumer-level questionnaires. The data should be a useful empirical base for future scholars.

The paper suffers limitations in terms of methodology. Primarily, the variable set dismisses the existing charging infrastructure of each pilot city because of a lack of public data. This will cause some bias in the empirical results because the existing charging infrastructure is positively related to EV 
purchase, which is a chicken-and-egg problem. When future data is available, it is worth re-doing the work. In addition, the estimation technique of the ordered logistic regression and the treatment of the panel data need more reflection, though the panel is too short to be a normal one. The cross-sectional results might not be the same in the panel scenario. Future data accumulation after several years will approach the facts more closely than this paper. Finally, this paper actually determines the significant correlation between policies and EV sales and shows their effectiveness, but fails to corroborate the causal relationship with an appropriate identification strategy, though national-level grand societal change, such as deteriorating air pollution, cannot explain the city-level difference and we have tried to control for some unobservable city-level factors. More delicate methods to identify and verify causality will be elaborated on in the future.

Acknowledgments: The authors are grateful to Zhengfeng Li, Baijie Zhang and Xiaoying Liu for their excellent research assistance.

Author Contributions: Guoqiang Zhang designed the entire research plan and wrote the paper with Yanmei Xu. Juan Zhang collected and analyzed the data.

Conflicts of Interest: The authors declare no conflict of interest.

\section{References}

1. Díaz Anadón, L.; Holdren, J.P. Policy for Energy Technology Innovation. In Acting in Time on Energy Policy; Gallagher, K.S., Ed.; Brookings Institution Press: Washington, DC, USA, 2009; pp. 89-127.

2. CATARC. Bluebook of China's New Energy Vehicle Industry Development; Social Sciences Press: Beijing, China, 2014.

3. Analysis on Global NEV Sales in 2015 and the Trends in 2016. Available online: http:/ /www.askci.com/ news/chanye/2016/02/15/152157x49r.shtml (accessed on 15 February 2016). (In Chinese)

4. European Countries' Passenger Car Registration in Dec. 2015. Available online: http:/ / www.caam.org.cn/ eurototal/20160202/1105185087.html (accessed on 2 February 2016). (In Chinese)

5. Ministry of Industry and Information Technology. Available online: http://www.miit.gov.cn/ (accessed on 14 December 2016). (In Chinese)

6. $\mathrm{Xu}, \mathrm{L} . ; \mathrm{Su}, \mathrm{J}$. From government to market and from producer to consumer: Transition of policy mix towards clean mobility in China. Energy Policy 2016, 96, 328-340. [CrossRef]

7. Howell, S.; Lee, H.; Heal, A. Leapfrogging or Stalling out? Electric Vehicles in China; Belfer Center for Science and International Affairs: Cambridge, MA, USA, 2014.

8. Zhou, Y.; Zhang, H.; Ding, M. How public demonstration projects affect the emergence of new industries: An empirical study of electric vehicles in China. Innov. Manag. Policy Pract. 2015, 17, 159-181. [CrossRef]

9. Hao, H.; Ou, X.; Du, J.; Wang, H.; Ouyang, M. China's electric vehicle subsidy scheme: Rationale and impacts. Energy Policy 2014, 73, 722-732. [CrossRef]

10. Popp, D.C. Induced innovation and energy prices. Am. Econ. Rev. 2002, 92, 160-189. [CrossRef]

11. Park, S. State renewable energy governance: Policy Instruments, markets, or citizens. Rev. Policy Res. 2015, 32, 273-296. [CrossRef]

12. Negro, S.O.; Alkemade, F.; Hekkert, M.P. Why does renewable energy diffuse so slowly? A review of innovation system problems. Renew. Sustain. Energy Rev. 2012, 16, 3836-3846. [CrossRef]

13. Varone, F.; Aebischer, B. Energy efficiency: The challenges of policy design. Energy Policy 2001, 29, 615-629. [CrossRef]

14. Gallagher, K.S. Hybrid cars: Development and deployment in Japan, the United States, and China. In Energy Technology Innovation: Learning from Historical Successes and Failures; Grübler, A., Wilson, C., Eds.; Cambridge University Press: New York, NY, USA, 2014; pp. 193-205.

15. Stern, P.C. Contributions of psychology to limiting climate change. Am. Psychol. 2011, 66, 303-314. [CrossRef] [PubMed]

16. Carrico, A.R.; Vandenbergh, M.P.; Stern, P.C.; Dietz, T. US climate policy needs behavioural science. Nat. Clim. Chang. 2015, 5, 177-179. [CrossRef]

17. Stern, P.C. Blind spots in policy analysis: What economics doesn't say about energy use. J. Policy Anal. Manag. 1986, 5, 200-227. [CrossRef] 
18. Zhang, X.; Xie, J.; Rao, R.; Liang, Y. Policy incentives for the adoption of electric vehicles across countries. Sustainability 2014, 6, 8056-8078. [CrossRef]

19. Wang, N.; Yan, R.; Liu, Y. Identifying consumer characteristics and public acceptance of electric vehicles in China. China Soft Sci. 2015, 10, 70-84. (In Chinese)

20. Zhang, X.; Rao, R.; Xie, J.; Liang, Y. The current dilemma and future path of China's electric vehicles. Sustainability 2014, 6, 1567-1593. [CrossRef]

21. Dietz, T.; Gardner, G.T.; Gilligan, J.; Stern, P.C.; Vandenbergh, M.P. Household actions can provide a behavioral wedge to rapidly reduce US carbon emissions. Proc. Natl. Acad. Sci. USA 2009, 106, 18452-18456. [CrossRef] [PubMed]

22. Carley, S.; Krause, R.M.; Lane, B.W.; Graham, J.D. Intent to purchase a plug-in electric vehicle: A survey of early impressions in large US cites. Transp. Res. Part D Transp. Environ. 2013, 18, 39-45. [CrossRef]

23. Diamond, D. The impact of government incentives for hybrid-electric vehicles: Evidence from US states. Energy Policy 2009, 37, 972-983. [CrossRef]

24. Siddiki, S.; Dumortier, J.; Graham, J.D.; Carley, S.; Krause, R.M. Exploring Drivers of Innovative Technology Adoption Intention: The Case of Plug-In Vehicles. Rev. Policy Res. 2015, 32, 649-674. [CrossRef]

25. Gallagher, K.S.; Muehlegger, E. Giving green to get green? Incentives and consumer adoption of hybrid vehicle technology. J. Environ. Econ. Manag. 2011, 61, 1-15. [CrossRef]

26. Wooldridge, J.M. Introductory Econometrics; Cengaga Learning Asia: Ho Chi Minh City, Vietnam, 2009.

27. Wang, N.; Yan, R. Research on Consumers' Use Willingness and Opinions of Electric Vehicle Sharing: An Empirical Study in Shanghai. Sustainability 2016, 8, 7. [CrossRef]

28. Zhang, Y.; Yu, Y.; Zou, B. Analyzing public awareness and acceptance of alternative fuel vehicles in China: The case of EV. Energy Policy 2011, 39, 7015-7024. [CrossRef]

29. Diamond, D. The impact of HOV lane incentives for hybrids in Virginia. J. Public Transp. 2008, 11, 57-76.

30. International Energy Agency (IEA); Organisation for Economic Co-operation and Development (OECD). Creating Markets for Energy Technologies; OECD Publishing: Paris, France, 2003.

31. Xue, Y.; You, J.; Liang, X.; Liu, H.C. Adopting strategic niche management to evaluate EV demonstration projects in China. Sustainability 2016, 8, 142. [CrossRef]

32. Harborne, P.; Hendry, C.; Brown, J. The development and diffusion of radical technological innovation: The role of bus demonstration projects in commercializing fuel cell technology. Technol. Anal. Strateg. Manag. 2007, 19, 167-188. [CrossRef]

33. Karlström, M.; Sandén, B.A. Selecting and assessing demonstration projects for technology assessment: The case of fuel cells and hydrogen systems in Sweden. Innov. Manag. Policy Pract. 2004, 6, 286-293. [CrossRef]

(C) 2016 by the authors; licensee MDPI, Basel, Switzerland. This article is an open access article distributed under the terms and conditions of the Creative Commons Attribution (CC-BY) license (http://creativecommons.org/licenses/by/4.0/). 